\title{
VERAPAMIL INDUCES DENTAL CARIES AND INHIBITION OF ALKALINE PHOSPHATASE IN RAT
}

\author{
VILELA-GOULART, M.G. ${ }^{1}$; NARESI, S. C. M. ${ }^{2}$; GASPAROTO, M. C. ${ }^{2}$; BASTOS-RAMOS, W.P. ${ }^{2}$ \\ ${ }^{1}$ Departamento de Ciências Fisiológicas, Fac. Odontologia, UNICAMP; \\ ${ }^{2}$ Departamento de Biociências e Diagnóstico Bucal, Fac. Odontologia de S. J. Campos, UNESP.
}

Calcium blockers are important therapeutic agents used in cardiovascular diseases. Their effects on osseous tissue are about unknown and an action on dental tissues was not previously studied. It was intended in the preent study to analyze the action of calcium blocker verapamil on dental caries induced by cariogenic diet and to correlate the results with alkaline phosphatase inhibition. Material and Methods. Thirty four Wistar male rats were divided in four groups as follows: a)- animals treated with normal diet and no drug (control 1); b)- animals treated with cariogenic diet and no drug (control 2); c)- animals treated with normal diet and verapamil (24 $\mathrm{mg} / \mathrm{rat} /$ day); c) animals treated with normal diet and verapamil. Salivary alkaline phosphatase was assayed in all the rats. A total of 160 teeth were examined under light stereoscopic microscope regarding to the presence of dental caries in enamel, dentine and pulp. Results. Results are presented as percentage of caries in each group. a)- Control 1-normal diet: no caries; b)- Control 2 - cariogenic diet: $48 \%$ of caries; c)- cariogenic diet and verapamil: $75 \%$ of caries; d)- normal diet and verapamil: $71 \%$ of caries. In the verapamil treated rats, a significant increase of dentine caries was observed. The drug increased salivar phosphatase alkaline activity. Conclusion. Verapamil significantly stimulated dental caries by itself, a result not dependent of the diet and the increasethe in salivary alkaline phosphatase activity; these two phenomena are possibly related between them.

Key Words: Verapramil; dental caries; alkaline phosphatase; cariogenic diet, wistar rat. 